\title{
PENERAPAN KONSEP KEADILAN TERHADAP PEMBANTU RUMAH TANGGA DALAM HUBUNGAN KERJA DENGAN MAJIKAN
}

\author{
OLEH : \\ Hj. NURSIMAH,SE.,SH.,M.H \\ (Dosen Tetap Fakultas Hukum Universitas Muhammadiyah Palembang)
}

\begin{abstract}
ABSTRAK
Hubungan kerja pembantu rumah tangga dengan majikan lahir dari perjanjian kerja dan yang hanya dibuat secara lisan, mengakibatkan terjadinya penipuan terhadap PRT yang dipekerjakan tidak sesuai dengan perjanjian kerja, misalnya tidak ada mekanisme dan sistem kerja yang jelas; upah rendah bahkan tidak dibayar serta jam kerja panjang,

Adapun permasalahan dalam tulisan ini penerapan konsep keadilan terhadap pembantu rumah tangga dalam hubungan kerja dengan majikan.

Konsep keadilan dalam kontrak antara pekerja dengan majikan dapat dipenuhi melalui ketentuan Pasal 1339 BW yang mengatur bahwa: "persetujuan tidak hanya mengikat apa yang dengan tegas ditentukan di dalamnya, melainkan juga segala sesuatu yang menurut sifatnya persetujuan dituntut berdasarkan keadilan, kebiasaan, atau undangundang. "Ketentuan tersebut dapat ditafsirkan bahwa atas dasar keadilan, kebiasaan dan atau karena undang-undang dapat memberikan hak kepada orang lain untuk menuntut suatu prestasi yang telah dilakukan dengan itikad baik.
\end{abstract}

Kata kunci : Konsep Keadilan, Pembantu Rtumah Tangga, Majikan

\section{ABSTRACT}

The domestic servant's employment relationship with the employer was born from a work agreement and which was only made verbally, resulting in the occurrence of fraud against domestic workers employed not in accordance with the employment agreement, for example there is no clear mechanism and work system; low wages are not even paid as well as long working hours,

The problem in this paper is the application of the concept of justice to domestic servants in working relationships with employers.

The concept of fairness in the contract between the worker and the employer can be fulfilled through the provisions of Article 1339 BW which stipulates that: "agreement is not only binding on what is explicitly stipulated in it, but also everything which by nature of the agreement is demanded based on justice, custom, or the law "These provisions can be interpreted that on the basis of fairness, habit and or because the law can give rights to others to demand an achievement that has been done in good faith.

Keywords: The Concept of Justice, Domestic Helpers, Employers

\section{A. Latar Belakang}

Pekerja Rumah Tangga adalah bagian dari masyarakat yang tidak berdaya di tengah modemisasi. Pekerja rumah tangga bekerja daiam lingkup rumah tangga yang sangat 
privat, dimana aturan main setiap rumah tangga berbeda-beda sehingga harus bisa mengikuti aturan main dalam keluarga majikan tersebut jika ingin tetap bertahan bekerja di rumah itu.Adapun pengertian Pekerja Rumah Tangga (PRT) dalam Pasal (1), Peraturan Menteri Ketenagakerjaan Rl No.2 Tahun 2015 tentang Perlindungan Pekeija Rumah Tangga adalah, "Orang yang hekerja pada orang perseorangan dalam rumah tangga untuk melaksanakan pekerjaan kerumahtanggaan dengan menerima upah dan/ imbalan dalam bentuk lain." Sedangkan pekerjaan kerumah-tanggaan adalah pekerjaan yang dilakukan dalam lingkup dan kepentingan rumah tangga. ${ }^{38}$

Dalam hubungannya dengan hubungan kerja antara majikan dan pembantu rumah tangga tidak selalu berjalan baik. Kekerasan terhadap pembantu rumah tangga yang dilakukan majikan seringkali terjadi. pembantu rumah tangga dan majikan, keduanya sering saling bertentangan, selalu dijumpai kesenjangan antara das sollen dan das sain . Kesenjangan antara "keharusan" dengan "kenyataan" ini disebabkan oleh adanya perbedaan pandangan dan prinsip antara kepentingan hukum (Perlindungan terhadap Pekerja) dengan kepentingan majikan.

Hubungan kerja pembantu rumah tangga dengan majikan lahir dari perjanjian kerja dan yang hanya dibuat secara lisan, mengakibatkan terjadinya penipuan terhadap PRT yang dipekerjakan tidak sesuai dengan perjanjian kerja, misalnya tidak ada mekanisme dan sistem kerja yang jelas; upah rendah bahkan tidak dibayar serta jam kerja panjang, Di sisi lain, hubungan kerja PRT- majikan juga bersifat subordinatif, dimana konsep hubungan ini didasarkan pada relasi kekuasaan yang timpang, majikan berada pada posisi superior, sementara PRT pada posisi subordinat,inferior. Posisi asimetris ini, dikuatkan dengan ketergantungan PRT terhadap majikan secara ekonomis, terlebih mereka juga membutuhkan pekerjaan, sehingga PRT tidak mempunyai daya tawar dan bersedia diupah rendah. Ruang gerak PRT yang sempit untuk menyuarakan kepentingannya, menyebabkan tidak adanya keberanian untuk melawan, ketika mendapatkan perlakuan tidak manusiawi dari majikan.

Akibat dari perjanjian kerja yang tidak jelas tersebut banyak bermunculan kasuskasus yang berhubungan dengan PRT hampir setiap saat disiarkan di televisi maupun radio dan diberitakan di surat-surat kabar sehingga menjadi satu penomena yang tidak dapat kita pungkiri bahwa permasalahan tentang PRT adalah permasalahan yang serius dan masif dan perlu menjadi perhatian Pemerintah maupun pemerintah daerah.

38 Sukanto Rcksohadiprodjo dan T.Hani Handoko, Organisasi Perusahaan, Teori Struktur dan Perilaku, Penerbil BPFE. Cetakan Ke-13, Yogyakarta, 2001. hlm. 254 
Penerbitan Permenaker No. 2 tahun 2015 tentang Perlindungan PRT pada tanggal 18 Januari 2015 merupakan sebuah terobosan hukum untuk memberi jaminan kepastian hukum kepada para Asisten Rumah Tangga dalam memperoleh hak-hak mereka dan melaksanakan kewajiban serta melindungi keberadaan PRT di Indonesia. Selama ini belum punya undang-undang yang mengatur mengenai pekerja domestik atau sektor rumah tangga.

\section{B. Permasalahan}

Berdasarkan latar belakang masalah yang telah disampaikan, maka rumusan masalah tulisan ini adalah : bagaimana penerapan konsep keadilan terhadap pembantu rumah tangga dalam hubungan kerja dengan majikan?

\section{Pembahasan}

Seorang pekerja rumah tangga adalah "seseorang yang dipekerjakan dalam pekerjaan rumah tangga di dalam sebuah hubungan kerja". Seorang pekerja rumah tangga mungkin bekerja atas dasar penuh waktu atau paruh waktu; mungkin dipekerjakan oleh sebuah rumah tangga atau oleh beberapa majikan (rumah tangga); mungkin tinggal di rumah tangga majikan (pekerja tinggal di dalam) atau mungkin tinggal di tempat tinggalnya sendiri (tinggal di luar).

Untuk melindungi hak Pekerja Rumah Tangga secara hukum, maka dapat perumusannya juga perlu dicantumkan hal-hal yang bersifat fundamental sehingga kepastian sebagai tujuan hukum dapat terwujud, penjabaran kedalam undang-undang ataupun perda juga merupakan atribusi UUD 1945 yang mengakomodir kepastian hak para pekerja yang wajib diberikan oleh majikan sebagai salah satu bentuk penerapan konsep keadilan dari majikan kepada pembantu rumah tangga.

Penerapan konsep keadilan dalam perjanjian kerja antara Pekerja Rumah Tangga dengan Pemberi Kerja sangat diperlukan untuk mewujudkan perjanjian yang saling menguntungkan satu sama lain. ${ }^{39}$ Badrulzaman mengatakan penerapan konsep ini sebagai asas persamaan hukum. Menurutnya, para pihak berada dalam persamaan derajat, tidak ada perbedaan dan mengharuskan kedua belah pihak untuk saling menghormati satu sama lain sebagai sesama ciptaan Tuhan YME. ${ }^{40}$

39 J.Satrio,Hukum Perikatan Yang Lahr dari Perjanjian Buku I, Citra Aditya Bhakty, Bandung,.2009

40 Mariam Darus Badrulzaman. Hukum Perikatan dalam KUH Perdata Buku Ketiga, Yurispridensi, Doktrin, serta Penjelasan ,Penerbit PT. Citra Aditya Bakti ,Bandung, 2015, hlm 89 
Berangkat dari hal tersebut, dibutuhkan konsep perjanjian kerja yang jelas antara Pekerja Rumah Tangga dan Majikan, karena fungsi utama dari suatu perjanjian adalah memberikan kepastian hukum tentang mengikatnya suatu perjanjian antara para pihak. Berdasarkan Teori Penerimaan, suatu perjanjian lahir pada saat diterimanya jawaban oleh pihak yang memberikan penawaran. Teori ini tidak memedulikan keadaan apakah surat jawaban tersebut dibuka dan dibaca isinya atau hanya dibiarkan tidak dibuka. Momentum lahirnya sepakat pada pokoknya adalah ketika surat jawaban tersebut sampai pada alamat si penerima surat. Teori ini juga merupakan jawaban terhadap kekurangan dari teori pengetahuan yang mana teori ini diterima oleh banyak sarjana. ${ }^{41}$

Model perjanjian kerja haruslah diatur dalam peraturan perundang-undangan, sehingga dapat berlaku memaksa untuk dipatuhi dan memberikan sanksi terhadap pelanggarnya. Namun untuk menjaga adanya kekosongan hukum dari hal tersebut, permasalahan kontrak kerja Pekerja Rumah Tangga dengan Majikan dapat didasarkan pada Pasal 1339 BW yang mengatur bahwa:"persetujuan tidak hanya mengikat apa yang dengan tegas ditentukan di dalamnya, melainkan juga segala sesuatu yang menurut sifatnya persetujuan dituntut berdasarkan keadilan, kebiasaan, atau undangundang. "Ketentuan tersebut dapat ditafsirkan bahwa atas dasar keadilan, kebiasaan dan atau karena undang-undang dapat memberikan hak kepada orang lain untuk menuntut suatu prestasi yang telah dilakukan dengan itikad baik.

Berdasarkan hal tersebut, menurut penulis meskipun Pekerja Rumah Tangga dikecualikan dari ketentuan UU Ketenagakerjaan, perjanjian kerja antara Pekerja Rumah Tangga dan Majikan baik itu tertulis maupun tidak tertulis karena adanya unsur paternalistik, namun hubungan hukum keduanya tetap terikat pada apa yang telah diatur dalam Pasal 1339 BW. Ketentuan Pasal 1339 BW jika diterapkan dalam konteks Pekerja Rumah Tangga, maka Majikan tidak dapat mempunyai dalih apapun untuk tidak memenuhi segala hak yang dimiliki oleh Pekerja Rumah Tangga, karena inilah yang disebut sebagai keadilan.

Terbitnya Permenaker No. 2 tahun 2015 tentang Perlindungan PRT pada tanggal 18 Januari 2015 merupakan sebuah terobosan hukum untuk melindungi keberadaan PRT di Indonesia. Pengertian perlindungan diartikan sebagai tempat berlindung, hal (perbuatan dan sebagainya) memperlindungi. ${ }^{42}$

41 J.Satrio, Op.cit,, hlm.261-261,1995

42 Pusat Bahasa Departemen Pendidikan Nasional, Kamus Besar Bahasa Indonesia, Edisi ketiga,2002, ,hlm 780 
Adapun bentuk perlindungan tersebut diatur dalam Pasal 7 Peraturan Menteri Tenaga Kerja Nomor 2 Tahun 2015 Tentang Perlindungan Pekerja Rumah Tangga disebutkan bahwa : Pekerja Rumah Tangga mempunyai hak:

a. memperoleh informasi mengenai Pengguna;

b. mendapatkan perlakuan yang baik dari Pengguna dan anggota keluarganya;

c. mendapatkan upah sesuai Perjanjian Kerja;

d. mendapatkan makanan dan minuman yang sehat;

e. mendapatkan waktu istirahat yang cukup;

f. mendapatkan hak cuti sesuai dengan kesepakatan;

g. mendapatkan kesempatan melakukan ibadah sesuai dengan agama dan kepercayaan yang dianutnya;

h. mendapatkan tunjangan hari raya; dan

i. berkomunikasi dengan keluarganya

Selain itu bentuk perlindungan hukum pembantu ramah tangga di kemukakan Asikin Zainal adalah sebagai berikut ${ }^{43}$ :

\section{1) Perlindungan Hak-Hak Dasar}

Hak adalah suatu kondisi yang melekat atas hidup manusia. Hak ini dimiliki oleh seseorang dan dapat dinikmati keberadaannya. Apabila seseorang memiliki hak tersebut, maka orang tersebut dengan bebas menggunakan haknya tanpa ada tekanan ataupun ancaman dari pihak manapun. Hak-hak dasar sebagai pekerja adalah hak yang melekat pada diri setiap pekerja sebagai konsekuensi menjadi pekerja. Hak butuh lahir sebagai konsekuensi adanya hubungan kerja antara buruh dan pengusaha/instansi. Hak buruh di Indonesia diatur dalam UU No.13 Tahun 2003 tentang ketenagakerjaan.

Pada faktanya mayoritas para Pekerja Rumah Tangga belum meyakini bahwa perlindungan hak-hak dasar mereka dalam peraturan perundang-undangan sudah terakomodir. Namun masih banyak yang meragukan adanya perlindungan terhadap mereka dan hanya sebagian kecil yang meyakini kalau hak-hak dasarnya sudah terjamin. Beda halnya dengan majikan, walaupun masih mayoritas yang ragu bahwa ada jaminan hak-hak dasar para pekerja dalam peraturan perundang-undangan, namun para majikan memahami bahwa sudah ada jaminan perlindungan hak-hak dasar Pekerja Rumah Tangga, hal ini berbanding terbalik dengan keyakinan dan pemahaman dari para Pekerja Rumah Tangga.

43 Asikin Zainal, Dasar-Dasar Hukum Perburuhan, Raja Grafindo Persada, Jakarta, 1993, hlm76 


\section{2) Perlindungan hak kodrat}

Pada prinsipnya pekerja atau tenaga kerja merupakan aset yang sangat berharga sebagai faktor utama dalam meningkatkan produktivitas dan kinerja suatu unit usaha/perusahaan/instansi tempat kerja, termasuk mempengaruhi tingkat kesejahteraan rumah tangga tempat bekerja. Oleh karena itu Pekerja wajib mendapatkan perlindungan, baik pada pekerja laki-laki maupun pekerja perempuan. Tetapi, dalam kenyataannya perlindungan pekerja banyak belum dilakukan secara memadai khususnya pada pekerja non formal atau sektor informal serta pada pekerja perempuan.

\section{3) Jaminan sosial}

Membahas tentang Jaminan Sosial, maka dapat ditelusuri dalam ketentuan perundang-udangan yang berlaku diantaranya: Pasal 28H UUD 1945 (amandemen kedua) yang mengatur bahwa: "Setiap orang berhak atas Jaminan Sosial yang memungkinkan pengembangan dirinya secara utuh sebagaimana manusia yang bermatabat", kemudia Pasal 34 Ayat (2) UUD 1945 (amandemen keempat), bahwa: "Negara mengembangkan sistem Jaminan sosial bagi seluruh rakyat dan memberdayakan masyarakat yang lemah dan tidak mampu sesuai dengan martabat kemanusiaan". Di samping itu, Ketetapan MPR No. X/MPR/2001 tentang laporan Pelaksanaan Putusan MPR RI oleh lembaga Tinggi Negara pada Sidang Tahunan MPR RI Tahun 2001 juga menugaskan kepada Presiden untuk membentuk sistem jaminan sosial nasional dalam rangka meberi perlindungan sosial yang lebih menyeluruh dan terpadu.

Berdasarkan Keputusan Presiden No. 20 Tahun 2002, dibentuk Tim Sistem Jaminan Sosial Nasional (SJSN) yang bertujuan menyusun rancangan undang-undang SJSN. Naskah Akademis yang disusun Tim SJSN kemudian diajukan ke DPR untuk menjadi landasan RUU SJSN, Cakupan naskah akademin tersebut meliputi jaminan sosial dengan pendekatan skema asuransi yang mewajibkan pekerja formal untuk mengikuti jaminan sosial pada aspek Jaminan kesehatan, jaminan kecelakaan kerja, pemutusan hubungan kerja, jaminan hari tua, pensiun dan kematian. Sedangkan bagi tenaga kerja informal dan masyarakat miskin belum tercantum. Jika Pekerja Rumah Tangga dikategorikan sebagai bagian dari pekerja informal, maka jelas bahwa Pekerja Rumah Tangga belum diwajibkan untuk mengikuti jaminan sosial pada aspek jaminan kesehatan, jaminan kecelakaan kerja, pemutusan hubungan kerja, jaminan hari tua, pensiun dan kematian sebagaimana diwajibkan bagi pekerja formal tersebut. 


\section{PENUTUP}

\section{Kesimpulan}

Konsep keadilan dalam kontrak antara pekerja dengan majikan dapat dipenuhi melalui ketentuan Pasal 1339 BW yang mengatur bahwa:"persetujuan tidak hanya mengikat apa yang dengan tegas ditentukan di dalamnya, melainkan juga segala sesuatu yang menurut sifatnya persetujuan dituntut berdasarkan keadilan, kebiasaan, atau undang-undang. 'Ketentuan tersebut dapat ditafsirkan bahwa atas dasar keadilan, kebiasaan dan atau karena undang-undang dapat memberikan hak kepada orang lain untuk menuntut suatu prestasi yang telah dilakukan dengan itikad baik.

Selain itu terbitnya Permenaker No. 2 tahun 2015 tentang Perlindungan PRT pada tanggal 18 Januari 2015 merupakan sebuah terobosan hukum untuk melindungi keberadaan PRT di Indonesia. Pengertian perlindungan diartikan sebagai tempat berlindung, hal (perbuatan dan sebagainya) memperlindungi.

Adapun bentuk perlindungan tersebut diatur dalam Pasal 7 Peraturan Menteri Tenaga Kerja Nomor 2 Tahun 2015 Tentang Perlindungan Pekerja Rumah Tangga disebutkan bahwa : Pekerja Rumah Tangga mempunyai hak:

a. memperoleh informasi mengenai Pengguna;

b. mendapatkan perlakuan yang baik dari Pengguna dan anggota keluarganya; c. mendapatkan upah sesuai Perjanjian Kerja;

c. mendapatkan makanan dan minuman yang sehat;

d. mendapatkan waktu istirahat yang cukup;

e. mendapatkan hak cuti sesuai dengan kesepakatan;

f. mendapatkan kesempatan melakukan ibadah sesuai dengan agama dan kepercayaan yang dianutnya;

g. mendapatkan tunjangan hari raya; dan

h. berkomunikasi dengan keluarganya

\section{Saran-Saran}

a. Perlu adanya platihan terhadap PRT sehingga PRT mengetahui dan memahami akan apa yang menjadi hak dan kewajibannya.

b. Perlu disosialisasikan kepada semua yang berkepentingan bahwa hubungan antara majikan dan pembantu rumah tangga tidak cukup hanya dibangun dalam bentuk 
hubungan kekeluargaan melainkan juga dijalin dalam bentuk hubungan formal supaya masing-masing memiliki kepastian

c. Disarankan ada aturan kesetaraan hak yang diterima pembantu rumah tangga dengan standar upah minimum regional.

\section{DAFTAR PUSTAKA}

Asikin Zainal, Dasar-Dasar Hukum Perburuhan, Raja Grafindo Persada, Jakarta, 1993

J.Satrio,Hukum Perikatan Yang Lahr dari Perjanjian Buku I, Citra Aditya Bhakty, Bandung,.2009

Mariam Darus Badrulzaman. Hukum Perikatan dalam KUH Perdata Buku Ketiga, Yurispridensi, Doktrin, serta Penjelasan ,Penerbit PT. Citra Aditya Bakti ,Bandung, 2015

Pusat Bahasa Departemen Pendidikan Nasional, Kamus Besar Bahasa Indonesia, Edisi ketiga,2002

Sukanto Rcksohadiprodjo dan T.Hani Handoko, Organisasi Perusahaan, Teori Struktur dan Perilaku, Penerbil BPFE. Cetakan Ke-13, Yogyakarta, 2001. 